\title{
LEWIS AND THE POSSIBILITY OF CONCEPTUAL ANALYSIS
}

M. S. GRAM

The Univergity of Iowa

In an early statement of a program of philosophical analysis, C. I. Lewis wrote the following:

The problem of a correctly conceived metaphysics ... is one to be resolved by attaining to clear and cogent self-consciousness. As it turns out, the problem of metaphysics is "the problem of the categories." ... Metaphysics is concerned to reveal just that set of major classifications of phenomena, and just those criteria of valid understanding, by which the whole array of given experience may be set in order and each item (ideally) assigned its. intelligible and unambiguous place. ${ }^{1}$

I am not concerned here to ask whether the problems that have traditionally been called metaphysical can be assimilated to the problems of clasification. What $I$ intend to do here is to examine the model of analysis according to which Lewis proposes to state the principles by which we organize our experience. And I want to discover the properties which Lewis assigns to this model of analysis, asking finally whether a conceptual analysis can in fact have the properties Lewis assigns to it.

But before I can begin to examine Lewis's model of analysis, there are two preliminary questions to be settled. The first concerns the object domain of categorial analysis. As I understand Lewis, what we are doing when we analyze categories is to give an account of what he calls intended

1 C. I. Lewis, Mind and the World Order (New York: Dover Publications, 1956), p. 10 and p. 12 (hereinafter cited as MWO). 
meanings. ${ }^{2}$ We are not analyzing words; nor are we analyzing things denoted by our intended meanings. I do not offer what I have just said as an explication of what an intended meaning is. All I wish to point out is that Lewis's intended meanings are not reducible to either words or things.

The second preliminary question concerns the distinction between a category and other intended meanings: What, exactly, is the basis of this distinction? In general, Lewis says that a category is a classification of a kind of reality, speaking of categories as "those basic concepts, determining major classes of the real."s But this does not give us a very clear understanding of the distinction; for Lewis elsewhere says that every concept is a classification of some kind of reality or other. Thus the distinction between concepts and categories depends upon an antecedent criterion for deciding what is to count as a basic concept. And this Lewis does not give us." Nothing I am about to say will depend upon our ability to give such a criterion. For my arguments will apply equally to concepts and their more important brethren, the categories.

\section{The Properties of a Conceptual Analysis}

There is one main support of Lewis's model of analysis which I want to consider. It consists in Lewis's claim that the analyses we give of categories are expressed by analytic propositions. At one place, for example, he says that "the a priori is not a material, truth, delimiting or delineating the content of experience as such, but is definitive or analytic in its nature." Now it is not hard to understand why a

2 MWO, pp. 230ff.

3 MWO, p. 250.

4 MWO, pp. 262-263.

- I have explored other attempts to distinguish categories from ordinary concepts in my "Transcendental Arguments", Nous, vol. 5 (1971), pp. 15-28; cf. also my "Categories and Transcendental Arguments", passim (forthcoming).

MWO, p. 231; italics in the original. 
categorial analysis must, on Lewis's theory, be analytic. Every such analysis states. what we mean by a concept we apply. If the sentence expressing the analysis were not analytic, then it would not state what we mean when we think a given concept. This is just a consequence of what Lewis understands by analyticity. ${ }^{7}$ An analytic sentence states on the right-hand side the parts of a cluster of concepts which are not distinguished by the expression occurring on the left-hand side of such a sentence. The symbols on the right-hand side express the cluster of concepts symbolized on the left-hand side. An analysis is analytic, then, because it expresses an identity of meanings. And we discover this identity by making reference to a definition of the terms occurring in the analysis. If no such identity of meanings were present in an analysis, then the right-hand side would fail to tell us what we think in the concept which we are trying to analyze.

This, then, is the support of Lewis's model. The entire weight of the model is, however, supported by the notion of identity of meaning. . And this, in turn, is clarified by what Lewis calls an explicative sentence. ${ }^{8}$ Let us suppose that we have a categorial analysis which states an identity of meaning. Lewis distinguishes such a sentence from two other kinds of sentences with which it is likely to be confused. In the first place, an explicative sentence does not merely relate a symbol to a symbol; it is not, in other words, an abbreviation which is introduced to license the replacement of one expression by another. " $[P \equiv Q]$ ' $={ }_{D f}$. ' $(x)[P x \equiv Q x]$ '" is an example of an abbreviation. It is a relation of one symbol to another. You can have an abbreviation without even mentioning an identity of meaning. And if we have a genuine identity of meaning, you have something more than an abbreviation. For you can change an

7 C. I. Lewis, An Analysis of Knoraledge and Valuation (LaSalle, Ilinois: Open Court, 1962), p. 152 and p. 154 (hereinafter cited AKV).

$8 \mathrm{AKV}$, pp. 99ff. 
abbreviation by changing the symbols. You cannot change an identity of meaning by changing the symbols used to express it. In the second place, an explicative sentence is to be distinguished from a dictionary definition. The sort of definition found in dictionaries relates a symbol to a meaning. We discover, for example, that 'tod' is used to mean 'small child' by consulting a dictionary. An this tells us that a certain meaning is expressed by a certain symbol in a natural language.

An explicative sentence properly so called is to be dis. tinguished both from an abbreviation and a dictionary definition. Unlike an abbreviation, an explication relates a meaning to a meaning. An explication clarifies the meaning expressed by a certain symbol. One famous example of an explicative definition occurs in the foundations of arithme. tic. When the statement occurs that "zero" means "the class whose sole member is the null class", this has been held to be an explication of what we mean by "zero". This kind of definition does not introduce a fiat according to which two symbols can be mutually interchanged. Still less is it a claim about how a meaning is to be symbolized. What we are told by an explication is something about what we think when we entertain a concept, not something about how we choose to express what we think. Thus Lewis can say that "neither stipulations nor empirical facts of linguistic usage can in any way determine or affect a relation of meanings". This should enable us to understand why Lewis reserves the predicate ". . is analytic" for explicative sentences. Abbreviations are neither analytic nor synthetic. They are stipulations made without any interpretation of the terms whose interchangeability is licensed. Dictionary definitions are synthetic. For even though a meaning is involved in such definitions, what we are claiming is that an expression is used to express a meaning. And this gives us empirical information about words. It does not tell us what we think when we

- AKV, p. 147. 
entertain a meaning. ${ }^{10}$ An explicative sentence is analytic because it expresses an identity of meaning.

\section{The Difficulty with this Theory}

There is, however, a difficulty with this model of analysis which seriously threatens Lewis's theory. I propose to show this by asking what Lewis takes to be the relata in explicative sentences. He says that an analysis expresses a relation between two meanings. But if this is so, then in what sense is one meaning the analysis of the other? The problem here is this. If there are really two separate meanings which are brought together in an explicative sentence, then the sentence will fail Lewis's conditions for a conceptual analysis. For the meaning expressed by the analysans will not be the same meaning as that expressed by the analysandum. But if this is so, then what we are given by such a sentence is not an analysis at all.

We might try to give a different interpretation of what Lewis says about the relation of meanings in a categorial analysis. We might deny that there are really two different meanings in an analysis and hold instead that the relation of meanings in an explicative sentence is the relation that every meaning has to itself, namely, that of identity. If we take this way out, the analytic character of such a sentence will be preserved. For the meanings of the expressions com: prising the analysis will not be different. But what we preserve here will, however, be retained at a disastrous price. For if the relation in an explicative sentence is that of identity, then in what sense is an analysis informative? We will, to be sure, be informed about the linguistic expressions which we use to express the identity. But this is not at all the kind of information that we are supposed to be given by such an analysis. For, on Lewis's theory, we are supposed

$10 \mathrm{Cf} . \mathrm{AKV}$, p. 156: “... the conventions of language determine no analytic truth but only how it is to be expressed". Cf. also AKV, p. 153; pp. 107-110; pp. $143-148$; pp. 150-151; pp. 152-153; pp. 155-157. 
to be informed about what we think when we entertain a given meaning. And if the relation in explicative sentences is that of identity, then an analysans will simply not give us information about what we conceive when we conceive a meaning. All we will ever be told is something about how one and the same meaning is expressed.

There are two possible misinterpretations of the difficulty I am raising against which I should like to guard myself. First, I am not saying that Lewis's model reduces categorial analyses to claims about words. All I am saying is that the theory, as it stands, is not able to explain how a categorial analysis tells us anything more about the analysandum than that it is expressed by the words comprising the analysans. Now this information is purely linguistic, although this fact does not make a categorial analysis into a claim about words. It merely means that such an analysis would do nothing but exhibit a linguistic relation of which we are not aware. And exhibitions of such relations, while they pertain to words, are different from claims about words.

It would also be a misinterpretation of the difficulty I am raising should one think that I am raising what has been known as the Paradox of Analysis. What we have come to understand by this paradox is a problem about the logical equivalence of analytic and tautological propositions. Let me make this clear by the following trivial example. It has been held that sentences like

(1) Man is a rational animal are reducible to sentences like

(2) Man is man.

This is done by interchanging "rational animal" with "man" for all occurrences of the latter. Now if substitutivity preserves equivalence, the paradox of analysis results when it is asked how (1) and (2) can be identical in meaning. They are, at most, logically equivalent: We can infer from the truth or falsity of one of them to a similar truth value for 
the other. (1) and (2), then, can have the same truth value and still have different meanings or senses. And this leaves the present difficulty where it was before. The issue con. cerns the relation between the terms in (1): We want to know how any such proposition can inform us of anything except alternative ways of symbolizing the same meaning while it plainly purports to tell us about a relation of mean. ings. That (1) and (2) are logically equivalent propositions in the sense specified above does not clarify this issue.

The difficulty with Lewis's model remains. But perhaps we can patch up the model as follows. Let us hold, as Lewis does, that a categorial analysis states an identity of meaning. But supose that we hold, further, that from this fact alone we cannot infer that the only information we get from an analysis is linguistic. For it can be claimed that we can be in various states of enlightenment about the meanings that we have. And what a categorial analysis does, so it could be held, is to state explicitly what all who conceive a certain concept know implicitly when they classify experience. On this reconstruction, an analysis gives us information about meanings and not just about words because we can be in varying degrees of enlightenment about our meanings. The crucial move here, then, is the introduction of a distinction between two different cognitive attitudes which we can have to our meanings. And this is a distinction which Lewis makes when he says:

To know in the sense of familiarity and to comprehend in clear ideas are, of course, quite different matters ... Just this business of bringing to clear consciousness and expressing coherently the principles which are implicitly intended in our dealing with the familiar, is the distinctively philosophic enterprise. ${ }^{11}$

11 MWO, p. 17, p. 31 ; cf. pp. 87-88; cf. my discussion of this issue with respect to Moore's paradox of analysis in my "The Paradox of Analysis", in Studies in the Philosophy of G. E. Moore, E. D. Klemke, editor (Chicago: Quadrangle Books, 1969), pp. 258-275. For an alternative theory of the relation between concepts and meanings, see my earlier article, "Frege, Concepts, and Ontology", in Essays on Frege, E. D. Klemke, editor (Urbana, Illinois: University of Illinois Press, 1968), pp. 178-199. 
What Lewis is saying here is, I believe, this. When we recognize objects of certain kinds and discriminate them from other objects, we show a certain kind of grasp of concepts. This ability to discriminate between objetcs in our experience is a pre-analytic knowledge of our concepts. A con. ceptual analysis, however, gives us a different kind of knowledge of these same concepts. When we are able to give an analysis of the concepts we use, we know, explicitly what we knew implicitly beforehand.

But does this really help us to explain the sense in which a categorial analysis as Lewis conceives it can give us anything but linguistic information? I think not. For I do not think that it makes sense to say of anybody that he implicit. ly knows anything or that he implicitly grasps as concept. Let me begin my argument by referring to a passage where Lewis states this issue clearly. He says:

Any controversy as to whether a mind possesses a meaning whenever a term is used intelligently, would be useless because it would be verbal. The pertinent facts are sufficiently clear; that it may possess meaning in the sense of determining a consistent mode of behavior (such as the consistent use of a term) without our being able out of hand to specify the ground of our own discrimination, we can all of us testify ... It would be an anomalous use of language to deny meaning to terms which are used without this explicit consciousness of what is esential, especially since the use of terms, like other modes of deliberate behavior, is most frequently a matter of habit.$^{12}$

What Lewis is arguing here is true; but it does not prove what he takes it to prove. It does not, that is, prove that we have an implicit grasp of concepts. What I want to argue is

12 MWO, p. 87. For a more comprehensive examination of Lewis theory of analysis as it relates his philosophy in general, victor Lowe, "Lewis's Conception of Philosophy", in The Philosophy of C. I. Lewis, Paul Schilpp, editor (LaSalle Illinois: Open Court, 1968), pp. 23-59, as well as Lowe's "Categorial Analysis, Metaphysics, and C. I. Lewis", in The Jourral of Philasophy, vol. 55 (1958). Asher Moore's "Lewis's Theory of the A Priori", in Schilpp, op. cit., pp. 155-199, treats the same issue with more specific reference to Lewis's theory of a priori knowledge. 
that what he calls intelligent use of words cannot prove this, and for two reasons. First, the phenomena which Lewis talks about do not entail the implicit possession of any concept at all as an explanation of them. Secondly, they do entail at most an explicit knowledge of a partial analysis of a concept. Take these in turn.

Let us assume a case in which a man applies the word "lemon" to lemons and refuses to apply it to things that are not lemons. This is presumably the kind of thing that Lewis has in mind when he says that we can have an implicit grasp of concept. But let us suppose that the man who applies the word "lemon" to lemons is not able to give us equivalent expressions for the word in English or any other natural language; and let us further suppose that he is unable to tell us in virtue of what properties he applies the word. The point to be made here is that our man could conceiv. ably apply the word without having the concept of lemon at all. For he could have learned to associate the word with certain visual stimuli. Thus unless he is able to give some account of the concept, there is no justification to infer from the kind of phenomena which Lewis points out to the implicit possession of a concept. And the inference is not jus. tified because a person could do what Lewis required and still be ignorant of the concept of which he is presumed to have implicit possession. So the objection I have to the notion of implicit knowledge is this: Lack of possession of a concept is being illicitly equated with a peculiar kind of possesion -namely, implicit possession.

Perhaps the following example will make this clear. Let us again consider the man who applies the word "lemon" to those objects when they are presented to him but cannot give you an account of the rule he uses in applying the term. Of what concept can he be said to have an implict grasp? I take it that Lewis would hold that such a man has implicit knowledge of the concept of lemon. But I do not think that the evidence warrants any such conclusion. For 
the fact that the man applies the English word "lemon" to lemons in compatible with his having a very different concept of lemon from the one we take him to have. He might, for instance, be applying any number of concepts - like that of "physical object" or "yellow" - which he uses the word "lemon". But if this is so, then how does the mere use of the word enable us to say that the man has an implicit grasp of the concept of a lemon? It does not show this simply because it does not suffice to show that the man has any concept of "lemon" at all. I grant, of course, that we can make generally reliable inferences about concepts from the uses of words. But what I deny is that we can infer merely from what a man cannot tell us together with his use of a word to his implicit possession of the concept of which that word is the linguistic vehicle. Thus the second objection to Lewis's notion of implicit knowledge is this: it confounds the implicit grasp of one concept with the explicit grasp of a different concept.

But perhaps what Lewis means by implicit possession of concepts is one's ability to give a partial analysis of the concept one uses. On this account, we would qualify as im. plicitly possessing a concept when we could give some rule or other which we follow when we use the word. We would not need to give a complete analysis. If this is how Lewis is to be interpreted, then the difficulty I have raised would disappear. We would no longer be equating ignorance of a concept with a peculiar kind of possession. Nor would we be equating explicit possession of one concept with implicit possession of another.

Once this amendment is made, the general difficulty I have been raising with explicative sentences breaks out all over again. The difficulty can be put in the form of a dilemma. What does an explicative sentence explicate? Is it the explicit knowledge I have of the partial analysis of a concept? Or is it the implicit knowledge I might be said to have of the remainder? It cannot be the latter. For the only 
sense in which, on the present theory, I can have implicit knowledge of a concept is to have explicit knowledge of a partial analysis. So the only remaining alternative is to say that an explicative sentence explicates a partial analysis. And this will not do either. For I have an explicit grasp of the partial analysis - in which case the same problem arises about the sense in which an analysis can give me anything more than linguistic information.

The notion of an explicative sentence is, I conclude, no better of than it was before we tried to make the distinction between implicit and explicit knowledge. But before I give up on the notion altogether, I want to anticipate an objection that is sure to arise. Someone is sure to point out that I am misconceiving the relation of implicit and explicit knowledge in a conceptual analysis. For it could be held that I have misrepresented the way in which we have an implicit knowlelge of our meanings. And the objector could say that we do not know all the logical consequences that follow from the terms we use. ${ }^{13}$ If we regard the meaning of a term as a logical intension, as Lewis does, then we can go on to explicate the intension of a term as all that follows logically from it. And just as we do not know all the consequences or logical implications of our terms, so likewise we do not know fully the meaning of the terms we use. We grasp explicitly only certain of the consequences of our terms (that, for example, a square is a four-sided plane figure); others logically follow from them (that, for example, a square has equal angles). We can grasp the former without grasping the latter. And if we conceive of an analysis as a tracing out of the logical consequences of the words in our language, the notion of implicit knowledge becomes viable. For we do not mean by "implicit knowledge" that we have no grasp at all of a term; we mean only that we have no grasp of all the consequences of a term.

13 Cf. AKV, p. 25. 
My answer to this objection is as follows. It is, of course, true that we understand a term more fully by seeing its consequences exhibited. Yet, in what sense do we have any knowledge at all of the consequences of a term which can be deduced from it but which we do not know? If we do not know these consequences, then in what sense can we call our knowledge of them even implicit? Thus this rescue effort is a failure. Even if we give an account of analysis in terms of logical consequences, the same problem arises. For even if what is on the right-hand side of an analysis is an indefinitely large set of logical consequences, we still have the problem of how we can be informed of what is on the right-hand side that we did not know by grasping what is on the left-hand side. If we are told that we do not know the consequences of our terms, then there is no sense in which we grasp these terms. If we are told that we know some consequences, then we are still not told how an analysis stating these consequences can be informative in the relevant way.

The difficulty I am raising cannot, I conclude, be solved so long as we keep Lewis's model of analysis. But is this just a problem about the way we express an analysis; or is it a problem about the theory of meaning which underlies the model Lewis uses? I do not think that the problem is merely one of correctly stating an analysis. For I think that the problem really turns on the properties which Lewis takes an intended meaning to have. Judging from his discussion of explicative sentences, he takes a meaning to be a complex entity which is expressed in two ways, one of which contains separate expressions for elements in the meaning which are not represented by separate expressions in the analysandum. Now so long as you hold a theory of meaning like this, then the only way in which you can express a conceptual analysis is in terms of an explicative sentence. And so long as this is the only way in which you can express an analysis, then the problem I have raised cannot be 
solved without abandoning the theory of meaning which gives rise to it.

\section{An Alternative Theory}

In the remainder of this paper I shall sketch an alternative view of analysis which will answer the kind of difficulty I have raised with Lewis's theory. I begin by rejecting the notion of an intended meaning as a primitive term. What I propose to put in its place is an ability to apply words. The kind of ability $I$ have in mind is in part the capacity to apply a word correctly to objects and to refuse its application to others. But the ability must include more than this. To count as possessing a concept one must also be able to give the rule according to which he applies the word. This latter requirement distinguishes the kind of ability that is present in applying concepts form abilities like swimming and rowing. In the case of swimming and rowing, we obviously do not have to be able to account for the rules we follow. In the case of possessing a concept, we must be able to give the rule we follow in applying a word.

I do not want to say that we must be conscious of the rule while we apply the word. Nor am I saying that we must rehearse the rule to ourselves before we apply the word. We must be able to cite the rule governing our application as a condition of possessing a concept. What I am denying, however, is that we can possess a concept without being able to cite the rule governing the word we apply.

The character of a conceptual analysis will, on this view of what a concept is, be very different from the kind suggested by Lewis. There are three significant differences. First, on the view I am suggesting, the relation between analysans and analysandum will be different. It will be a relation between a word, which is mentioned and not used, and other expressions which name or describe procedures for applying the word. The relation here replaces the identity of meaning which was the relation in Lewis's explica- 
tive sentences. Consider a trivial example. An analysis of my concept of square would relate the wold "square" to a description of the procedure for applying it, which might run something like this: "Call something "square' if and only if, upon counting it is found to have four sides, upon measurement it is found to have equal sides, and upon measurement it is found to have equal angles."

The second major difference follows from this. The rela.tion between the analysandum and analysans will, on the view I am holding, not be a necessary relation. No contradiction will be generated if we apply a word and refuse to accept the rules which conventionally govern its application. This is just another way of stating the fact that an analysis is a logically contingent statement. For it is a statement about the fact that a certain word has a rule or rules governing its application. And this is just a fact about the word, not a necessary claim which it would be self-contra. dictory to deny.

The third major difference is this. It was impossible, on Lewis's view, to explain how an analysis could be informative in a way that was different than merely telling us that one meaning has different linguistic expressions. This dif. ficulty is answered on the present view. An analysis informs us of the rules for applying a word. Of course, we all know some rules for applying the words we use. And an analysis does not merely repeat this. What is informative about an analysis is that it seeks to formulate all the rules which govern our application of the word. While everyone who has a concept must know some rule for applying a word, it does not follow that he will know most of the rules used for applying it. Most of the time there will be no great diversity of rules. But in things important enough to talk about - like, for example, the concepts of individual or possibility- we will use a number of different rules to apply the same words in different contexts.

Consider the kind of analysis one might give of the con- 
cept of possibility. Such an analysis would list such procedures of application as the following. First, we call something "possible" if the description of the state of affairs does not generate something of the form p.-p. Secondly, we call something "possible" if the description of the state of affairs is not incompatible with physical laws. Finally, we call something "possible" when the end envisioned by an agent can be actualized. What is informative about this analysis is just that the word "possible" is used to cover several different kinds of rules of application. Although we all use one or the other rule at most times, we do not genrally distinguish one from the other. This, I think, is what is informative about an analysis.

What $\mathrm{I}$ have been doing so far is merely to sketch an alternative view of what an analysis is which avoids the kind of difficulty which I think is fatal to Lewis's theory. The view that I have presented here is old; and, perhaps for that reason, it has been engulfed in objections. The main objection is deceptively simple. Many of us want to say that we can entertain a concept of something without entertaining any of the rules which I would follow to find whether something falls under the concept. This is a very persuasive objection, and it arises in different forms.

The first form in which this objection occurs is that I am confusing the meaning of a word with the criteria of its application. Let me illustrate this objection by considering the concept of "whale". We can find out whether an object is a whale in a number of different ways. Sometimes we discover this by ruling that anything is a whale that exhibits certain perceptual properties. This is, in fact, how we most often apply the word. But a zoologist will not rely on this criterion. He will rule that the word can be applied only to those things that have mammary glands. What our objector is holding, then, comes to this. We must distinguish between the meaning of the word, which remains constant, and the rules for the application of the word, which may 
vary. Both rules for applying the word may in fact be effective. But the concept we have of whale does not change when we change the rules we use. Thus, it is urged, if we do not recognize the distinction between meaning and rules, we will be committed to saying that the meaning of "whale" changes when we change the method of applying the word. And this is false.

It is not clear to me what anyone making this objection could cite as evidence for his claim. It is, of course, clear that something remains constant even though we may change the rules for applying a word. But it is not at all clear that the objector has correctly identified what remains constant. What $I$ have in mind is this. When we give different rules for applying a word, the object denoted by the word certainly does not change. In this sense whales remain what they are whether I choose to apply the word "whale" according to the visual Gestalt that a whale has or according to another rule. Thus the meaning of "whale" does not change if we understand by "meaning" the object meant. But it does not follow from this that our concept of a whale remains the same through various changes of rules. And there are very good reasons for saying that it does not. The concept that, say, a zoologist has of a whale will relate to a whole network of concepts about the physiology and anatomy of whales; the concept that a layman has of the same animal will have no such relation to these other concepts. Thus what we understand by the word "whale" will surely differ when we change the rules for applying the word. And if someone insists that the meaning does remain constant despite this change, what he will have to explain is how a layman can be completely ignorant of the zoologist's criterion for applying the word and can still be said to possess the same concept as the zoologist. We can say, of course, that the layman and the zoologist have concepts of the same thing -from which it does not follow, however, that they have the same concept. 
There is a different, yet related, objection to the view of a concept that I have proposed here. I have said that you have given your concept of $f$ when you have given the rules for applying a word to $f$ 's. It is here that the objection is raised. For it has been held that any such account of concepts is a failure because the concept of the rules for applying a word is not the same concept as the one I have of what the word is applied to. This objection comes, then, to this. What my account allegedly confuses is the concept of a rule with the concept of a thing to which the rule is applied.

The objection breaks down on an illict inference. What I have said is that my concept of a $f$ is analyzable into a word denoting $f$ together with the rules for the application of the word. It does not follow from this that my concept of $f$ is my concept of the rules for applying words to $f s$. It follows only that my concept of $f$ consists of the rules themselves as distinct from my concept of those rules. Thus I can concede the point made in the objection and still hold my view of concepts. For the objection here assumes that I am committed to identifying rules with my concept of these rules. And this assumption is erroneous.

But once this has been said, there will, I am sure, be an opponent, unsatisfied with my account, who will offer the following objection. He will say that my account of what a concept is really assumes the view that $I$ am rejecting. When I specify the rule or rules for applying a word, what I assume is that certain things in our experience will count as giving us cases of the object to which the word refers. When a rule is given, what happens is that we include the result which we are seeking by applying the rule. Thus our rule for applying the word "physical object" will specify properties like spatio-temporal continuity as one of the features of our experience which count as justifying the application of the word. But if this is so, then is it not the case that I am merely assuming the truth of an explicative 
sentence according to which the concept expressed by "physical object" is somehow identified with the concept of such properties as spatio-temporal continuity? If this is true, then I am begging the whole issue. For it is precisely this kind of notion of conceptual analysis which I am concerned to reject.

The issue here is solely whether formulation of the rules for applying a word assumes an explicative sentence. I do not think that it does. What is assumed, however, is that words like "physical object" have certain implication relations to other words. And for this reason $I$ am assuming that the referents of the implications of a word under analysis can be mentioned in giving the rules for applying the word. But the notion of an implication relation between words does not assume a theory of concepts; for an understanding of what logical implication is does not presuppose a prior understanding of what it is to be a concept. Thus my answer to the present objection is that $I$ am in fact assuming something very different from what is assumed by Lewis's explicative sentences. I assume the notion of logical implication to hold between the rules for appling words. But this is not to assume anything about concepts; and hence it is not to assume anything about explicative sentences as Lewis understands them.

But this kind of answer may not satisfy somebody raising the present objection. He might attack my view that logical implication does not depend upon the introduction of anything like a relation of concepts or a relation of meanings. And he could develop the following answer. When I hold that the notion of logical implication can be explicated without any reference to reations between concepts, I presumably mean that sentences expressing logical implications can be certified as truth functional tautologies or substitution instances of theorems in the predicate calculus. And it is here that our hypothetical objector would want to accuse me of merely pushing the problem one step back. For he 
could say that our translation of sentences in a natural language into a formal calculus assumes that we have an antecedent grasp of the meanings of the expressions comprising them. We must make this assumption; for otherwise how could we recognize that the translation we have given is a correct one? And if we must make this assumption, am I not, after all, merely assuming the kind of sentence which Lewis calls an explicative definition?

The issue that this objection raises is whether we are committed to taking Lewis's notion of an intended meaning to explicate the relation of logical implication. And I do not think that we are committed to doing this at all. Consider the expression "brother". That it implies such expressions as "male sibling" depends upon a definition. But all we have to assume here is the kind of definition which Lewis calls an abbreviation. We are forced, that is, to assume only that there are expressions in natural language which are used interchangeably. But this is not the same thing as to assume that cases of interchangeably expressions are cases of identity of concepts. What I am suggesting, then, comes to this: To explain how we grasp certain expressions as having the same meaning does not require that we introduce the notion of an explicative definition as Lewis understands it. We do, of course, have problems about giving an effective criterion of how we discover, in any given case, whether two expressions are in fact used interchangeably. But that is an entirely different problem. All I am arguing is that the mere introduction of definitions as a way of explaining our knowledge of logical implication does not assume explicative definitions. 
RESUMEN

No me interesa saber si los problemas tradicionales de la metafísica pueden ser asimilados a los problemas de la clasificación. Lo que sí me interesa es examinar el modelo de análisis conforme al cual C. I. Lewis propone establecer los principios por medio de los cuales organizamos nuestra experiencia. Además quiero descubrir las propiedades que Lewis le atribuye a su modelo de análisis, $\mathrm{y}$, por último, preguntarme si el análisis conceptual puede, en efecto, tener las propiedades asignadas por Lewis.

Antes de entrar a examinar la teoría de Lewis consideremos ciertas cuestiones preliminares: a) Examinar el dominio de objetos del análisis categorial. Según Lewis lo que hacemos al analizar las categorías es informar acerca de lo que él llama significados intencionales, y, éstos no son reducibles ni a palabras ni a cosas. b) ¿Cómo se distingue una categoría de los demás significados intencionales? Lewis nos dice que éstas son clasificaciones de un tipo de realidad: los conceptos básicos que determinan las clases mayores de lo real. Pero esto no nos sirve para su distinción, ya que para él todo concepto es una clasificación de algún tipo de realidad. Entonces, la distinción entre categoría y concepto nos remitiría al problema de encontrar un criterio para decidir lo que es un concepto básico.

Las propiedades del análisis conceptual son: a) El análisis de categorías se expresa por medio de proposiciones analíticas. Es difícil entender por qué debe ser el análisis conceptual analítico, según la teoría de Lewis. El que sea analítico es una consecuencia de lo que Lewis entiende por analiticidad, el análisis es analítico porque expresa una identidad de significados. b) La oración explicativa se distingue de la abreviación porque ella no relaciona meramente un símbolo con otro. No se puede cambiar la identidad de significados al cambiar los símbolos que se usan para expresarla; la oración explicativa relaciona un significado con otro significado. c) Por último, las oraciones explicativas se distinguen de las definiciones de diccionario en que éstas son sintéticas, mientras que aquellas son analíticas, ya que expresan una identidad de significados.

Las dificultades que presenta esta teoría son: a) $\mathrm{Si}$ el análisis expresa la relación entre dos significados, entonces los significados en cuestión no serían el mismo, y entonces no sería ya un análisis. 
Por mi parte, considero que la relación de significados en una oración explicativa es la relación que todo significado tiene consigo mismo, esto es: la relación de identidad. Pero si es esto así, ¿en qué sentido sería informativo un análisis? Seríamos informados acerca de las expresiones lingüísticas que se usan para expresar la identidad, pero esta clase de información no es la que se supone que un análisis nos da. (Esta teoría, presentada de esa manera no puede explicar de qué manera un análisis categorial nos puede decir algo más en el analysandum de lo que es expresado en el analysans.) Esta información es lingüística; pero a pesar de este hecho no reducimos el análisis categorial a una mera afirmación acerca de palabras; sostengo que el análisis exhibe una relación lingüística de la cual no somos conscientes. Las exhibiciones de dichas relaciones, no obstante que pertenecen a las palabras, son diferentes de las afirmaciones sobre palabras (lingüísticas).

Podemos tener varios grados de claridad acerca de los significados que poseemos; lo que hace el análisis categorial es establecer explícitamente lo que todos los que conciben un cierto concepto conocen implícitamente cuando clasifican una experiencia. La posesión implícita de un concepto consiste en la habilidad que se tiene para dar un análisis parcial de él, esto es, cuando podemos dar algunas reglas ( $u$ otras que deducimos) cuando usamos una pa-, labra.

Si siguiendo a Lewis entendemos por significado de un término la intención lógica, ésta consistiría en todas las consecuentias lógicas que se siguen de tal término. De la misma manera como no conocemos todas las consecuencias lógicas de los términos, así no sabemos el significado total de los términos que usamos. Siguiendo a Lewis ¿en qué sentido sería informativo el análisis que estableciera estas consecuencias? Este problema no puede ser resuelto sin abandonar la teoría del significado de Lewis.

La teoría alternativa que propongo se distingue de la de Lewis en que: a) rechaza que la noción de significado intensional sea un término primitivo, en su lugar propongo la habilidad que se tiene para aplicar las palabras: la capacidad para aplicar correctamente una palabra a ciertos objetos y rehusar aplicarla a otros. b) La relación entre analysans y analysandum no es entre significados, sino que consiste en una relación entre una palabra que es mencionada y otras expresiones que nombran o describen los procedimientos para aplicarla. c) La tercera diferencia radica en que la relación entre el analysandum y el analysans no es una relación necesaria; no se origina ninguna contradicción si aplicamos una palabra y no aceptamos las reglas que convencionalmente gobiernan su aplica- 
ción. En otras palabras, el análisis es un enunciado lógicamente contingente. d) Por último, siguiendo a Lewis no era posible explicar de qué manera un análisis es informativo de manera diferente a como lo es una información meramente lingüística. Un análisis es informativo en el sentido de que busca formular todas las reglas que gobiernan la aplicación de la palabra. Todo aquél que tiene un concepto conoce algunas de las reglas para aplicar una palabra, pero de esto no se sigue que conozca la mayoría de las reglas. Ejemplo: el concepto de posibilidad; para aplicar la palabra "posible" usamos diferentes reglas.

Se puede objetar esta teoria y decir que pueden variar los criterios para aplicar una palabra y mantenerse el significado, por ejemplo: son diferentes los criterios de aplicación que tiene un zoólogo para la palabra "ballena" de los que tiene un lego y, sin embargo, el significado de "ballena" es el mismo. En este caso, lo que no cambia es el objeto significado, pero de esto no se sigue que el concepto permanezca siendo el mismo.

Otra objeción a mi tesis es la que afirmaría que lo que sostiene es que se. puede tener el concepto de $f$ cuando se han dado las reglas para aplicar la palabra a las $f$ 's, pero que el concepto de las reglas para aplicar la palabra no es el mismo que el concepto al cual se le aplica la palabra. Esta objeción confunde evidentemente el concepto de la regla con el concepto de la cosa al cual se le aplica la regla. La inferencia hecha en esta objeción es ilícita. Lo que sostengo es que mi concepto de $f$ es analizable por una palabra que denota $f$ junto con las reglas para la aplicación de la palabra. Pero de esto no se sigue que mi concepto de $f$ es mi concepto de las reglas para aplicar las palabras a las $f$ 's, sólo se sigue que mi concepto de $f$ consiste en las reglas mismas como distintas de mi concepto de esas reglas.

Podría haber aún un oponente insatisfecho que ofreciera la objeción siguiente a mi tesis: decir que asumo la postura que rechazo. En otras palabras, que la formulación de las reglas para aplicar una palabra asume una oración explicativa. La idea de una relación de implicación entre palabras no asume una teoría sobre los conceptos, pues la comprensión de lo que es una implicación lógica no presupone una comprensión previa de lo que es un concepto. Lo que sí se asume es que sí hay implicación lógica entre las reglas para la aplicación de palabras.

Aún puede haber otra objeción: la traducción de las oraciones del lenguaje natural a un cálculo formal asume la comprensión de los significados de las expresiones. ¿Se asume la noción de significado intencional al explicar la relación de implicación lógica? 
Por ejemplo: ¿"hermano" implłca "varón célibe"? Lo que sí se asume es que hay expresiones en el lenguaje natural que son intercambiables, esto no es lo mismo que decir que los casos de expresiones intercambiables son casos de identidad de conceptos. Es cierto que existen problemas para dar un criterio efectivo para poder descubrir si dos expresiones son en efecto intercambiables, pero esto es enteramente otro problema. Lo que sostengo es que la mera introducción de definiciones como un medio para explicar nuestro conocimiento de la implicación lógica, no asume definiciones explicativas en el sentido en que lo sostiene la tesis de Lewis. 